\title{
Aortic enlargement in coarctation is not common in patients without a bicuspid valve: rethinking etiologies
}

\author{
Joel D McLarry, ${ }^{*}$ Craig S Broberg \\ From 17th Annual SCMR Scientific Sessions \\ New Orleans, LA, USA. 16-19 January 2014
}

\section{Background}

Aortic coarctation is considered an endothelial disorder. It is associated with bicuspid aortic valve (BAV), cerebral aneurysms, and aortic dilatation and dissection. Accordingly, guideline statements recommend complete aortic imaging in all coarctation patients. Yet is enlargement mostly seen in those with a coexisting bicuspid aortic valve?

\section{Methods}

Consecutive patients referred for cardiac MRI for repaired aortic coarctation, bicuspid aortic valve, or both were retrospectively reviewed. Patients with prior aortic valve or ascending aortic surgery were excluded, though prior coarctation intervention was not excluded. Maximum ascending aortic dimension was obtained, and averaged for patients with BAV alone, BAV and coarctation, or coarctation alone. Percentage of patients with aortic enlargement defined as a maximum diameter $>40 \mathrm{~mm}$ were calculated for each group, and appropriate comparisons made between groups.

\section{Results}

A total of 77 patients (58\% male, age $36 \pm 13.7$ ) were included in the study including 29 with BAV alone, 33 patients with BAV and coarctation, and 15 patients with coarctation alone. Average maximal aortic dimension was $43 \mathrm{~mm}, 34 \mathrm{~mm}$, and $29 \mathrm{~mm}$ in each group respectively ( $<0.001)$. Additionally, mean aortic diameter was less when comparing the coarct alone and BAV and coarct groups $(\mathrm{p}=0.03)$. Aortic enlargement $(>40 \mathrm{~mm})$ was present in $69 \%$ of BAV patients, but only $20 \%$ of BAV and coarctation patients, and no patients with coarctation alone $(\mathrm{p}<0.001)$.

\section{Conclusions}

In this cohort of patients referred for CMR, ascending aortic enlargement after repaired coarctation is uncommon in the absence of BAV, implying that aortic enlargement is not simply due to adverse pressure loading. The finding argues for a different endovascular physiology in BAV patients compared to those without.

Table 1 Aortic Coarctation, Bicuspid Aortic Valve, and Aortic Enlargement

\begin{tabular}{cccccc}
\hline & N & Age & $\begin{array}{c}\text { N with Aortic } \\
\text { Enlargement }\end{array}$ & $\begin{array}{c}\text { \% with Aortic } \\
\text { Enlargement }\end{array}$ & $\begin{array}{c}\text { Mean Maximal Ascending Aortic Diameter } \\
\text { (95\% confidence intervals) }\end{array}$ \\
\hline $\begin{array}{c}\text { BAV } \\
\text { alone }\end{array}$ & 29 & $46 \pm 15.3$ & 20 & 69 & $43.1(40.2-46.0)$ \\
\hline BAV + Coarct & 35 & $31 \pm 8.3$ & 7 & 20 & $34.0(31.5-36.5)$ \\
\hline $\begin{array}{c}\text { Coarct } \\
\text { alone }\end{array}$ & 13 & $46 \pm 15.7$ & 0 & 0 & $29.2(27.2-31.2)$ \\
\hline
\end{tabular}

Oregon Health and Science University, Portland, Oregon, USA 


\section{Funding}

None.

Published: 16 January 2014

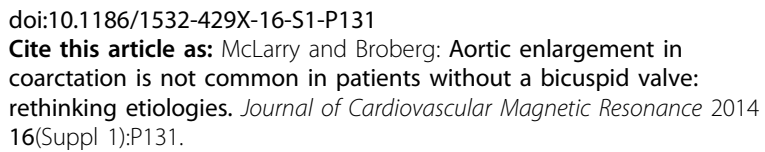

Submit your next manuscript to BioMed Central and take full advantage of:

- Convenient online submission

- Thorough peer review

- No space constraints or color figure charges

- Immediate publication on acceptance

- Inclusion in PubMed, CAS, Scopus and Google Scholar

- Research which is freely available for redistribution 